\title{
Akhenaton, Moses og den moderne monoteismedebat
}

\author{
PAUL JOHN FRANDSEN
}

ENGLISH ABSTRACT: The essays provides an extensive survey of Jan Assmann's theory on the relationship between monotheism and violence with a special focus on the question of the religio-historical background for the emergence of monotheism. The article discusses Assmann's argumentation for a connection between the alleged religious revolution under Akhenaten and the later Jewish monotheism. Additionally, it is emphasised how the two religions differ from each other. Finally, Frandsen underlines how the relationship between the Aten religion and the later Jewish monotheism first and foremost should be conceived of in terms of history of memory, which establishes a connection between the two entities.

DANSK RESUMÉ: Artiklen er en grundlæggende præsentation af Jan Assmanns teori om sammenhængen mellem monoteisme og vold med særlig fokus på spørgsmålet om de religionshistoriske forudsætninger for monoteismens fremkomst. I bidraget drøftes Assmanns påpegning af en forbindelse mellem den æoyptiske religiøse revolution under Akhenaton og den senere jødiske monoteisme. Det fremhæves imidlertid også, hvordan de to adskiller sig fra hinanden. Endelig pointeres, hoordan relationen mellem Atonreligionen og en senere jødisk monoteisme først og fremmest skal ses $i$ lyset af et stykke erindringshistorie, der etablerer forbindelsen mellem de to.

KEYWORDS: Jan Assmann, Armana-period, Akhenaten, Mosaic distinction, Mnemohistory, Monotheism and Violence.

Emnet for det følgende er Akhenatons religiøse revolutions virkningshistorie. Grundlaget for fremstillingen er en række værker af den tyske ægyptolog og kulturhistoriker Jan Assmann. I 1997 udgav han bogen Moses the Egyptian. The Memory of Egypt in Western Monotheism, hvori han argumenterer for, at der er en sammenhæng mellem Ak- 
henatons monoteisme og jødedommen, idet den sidste blev til som en modreligion til den ægyptiske - dvs. Akhenatons - monoteisme. Bogens centrale ærinde var dog ikke monoteisme som sådan. Dens primære formål var at supplere historien om den europæiske Ægyptensreception med en genopdagelse af et centralt emne i det 17. og 18. århundredes debat, nemlig påstanden om at monoteismen i sidste instans skulle stamme fra Ægypten, fordi man antog, at Moses var ægypter. Det er indholdet af kapitel 4 i Moses the Egyptian, der netop har undertitlen The Memory of Egypt in Western Monotheism. At bogen af de fleste kritikere blev opfattet som et frontalt angreb på kristendommen, ja, på monoteistiske religioner i almindelighed, kom angiveligt bag på Assmann. At bogen også blev opfattet som antisemitisk, fandt han sårende.

Assmann mener ikke, at der er en i normal forstand umiddelbar sammenhæng mellem Atonreligionen og jødedommen. Han hævder derimod, at forbindelsen er udformet i senere tiders erindring om fortiden. Moses the Egyptian vakte en voldsom opsigt og blev hurtigt oversat til flere sprog, herunder selvfølgelig tysk. Assmanns synspunkter blev drøftet på konferencer og i talrige artikler. Assmann blev, som nævnt, beskyldt for at være anti-semit, en påstand som efter min bedste opfattelse er helt ubegrundet. I 2003 kom så Assmanns svar på kritikken med bogen Die Mosaische Unterscheidung oder der Preis des Monotheismus (Den mosaiske adskillelse/skelnen eller monoteismens pris). Bogen indeholder også et genoptryk af fire artikler af fire af hans kritikere. Assmanns seneste bidrag til debatten er en række artikler samt bøgerne Monotheimus und die Sprache der Gewalt, som udkom i foråret 2006, og Thomas Mann und Ägypten. Mythos und Monotheismus in den Josephsroman, ligeledes fra 2006. Jeg skal i det følgende redegøre for hovedtrækkene i denne diskussionen om monoteismens oprindelse og karakter med hovedvægten på Assmanns synspunkter; pladsen tillader desværre ikke en mere detaljeret diskussion af hele debatten, som internationalt føres med stor ildhu. For at forstå Assmanns synspunkter må det indledningsvis gøres klart, hvad der menes med den mosaiske skelnen - et begreb, han tillægger en afgørende rolle i karakteristikken af monoteismen.

Monoteistiske religioner er, som Assmann forstår det, 'sekundære religioner'. De er ikke lige så gamle som menneskeheden, og det er derfor i princippet muligt at sige noget om deres begyndelse. Monoteisme indfører et afgørende skel mellem falsk og sand religion, mellem sande og falske guder, m.v. Monoteistiske religioner har et negativt potentiale i den forstand, at de afgrænser sig såvel udad- som indadtil. Dette leder hen til spørgsmålet, om monoteisme bærer intolerance og vold i sig. Monoteismen introducerer også troen - $\mathrm{i}$ betydningen at anse noget for sandt, som ikke kan begrundes videnskabeligt. I de primære religioner er der ikke tale om tro. Ægypterne troede ikke på deres guder, guderne levede og var til stede i deres verden. Guder kunne fødes og dø, og de daglige tempelritualer havde bl.a. til formål at få guderne til at tage ophold 
i deres statuer. ${ }^{1}$ Akhenatons religion var verdens første monoteistiske religion, og det kunne derfor være fristende at lade denne skelnen mellem sandt og falsk, tro og viden, osv. få navn efter Akhenaton eller hans guddom Aton eller hans by Amarna. Når Assmann ikke desto mindre ikke taler om Akhenatons skelnen eller Amarna-religionens skelnen, men derimod bruger den mosaiske tro eller jødedommen som begreb, skyldes det, at Akhenatons religion gik i glemmebogen, mens jødedommen fik verdenshistoriske konsekvenser. Disse antydninger vil blive uddybet i det følgende.

\section{Erindringen om Akhenaton og Hyksos}

Akhetaten er i dag en død by, en ruinby. Byens oprindelige navn er udskiftet med Amarna, som også er blevet den moderne betegnelse for hele epoken. Men er Amarnakulturen - for nu at lave en arkæologisk inspireret terminologi - også død? Umiddelbart må svaret være et ja. Ganske vist har levnene fra Amarma-kulturen i moderne tid fået en høj fascinationskraft. De har givet inspiration til forfattere, billedkunstnere, komponister, kunsthåndværkere, psykologer, læger og mange andre. Men grundlæggende er og bliver interessen antikvarisk. Enkelte elementer fra Amarna-kulturen har dog fået et nyt liv efter genopdagelsen. Det drejer sig i første række om Akhenatons solhymne, som mange komponister har sat musik til. Og man kan også godt argumentere for, at Amarna-kulturen i eminent grad er genstand for en række projektioner af det moderne livs problemer og brydninger. Jeg nævner blot stikord som seksualitet og pacifisme. I det følgende skal det imidlertid handle om det fænomen, som ikke blot er det allermest centrale i hele Amarna-kulturen, men måske det område, hvor arven fra Ægypten er mest markant: monoteismen, dvs. troen på én gud. Akhenaton skabte en monoteistisk religion, og det første spørgsmål er nu, om dette forsøg har noget med de senere monoteistiske religioner at gøre.

Tanken om en mulig forbindelse er ikke ny. I takt med at tekster fra Amarna blev offentliggjort, fik de moderne læsere øje for det brud med fortiden, dvs. tiden før Amarna-perioden, som teksternes indhold gav udtryk for, og i 1894 kunne den amerikanske ægyptolog James Henry Breasted indlevere sin Berliner-disputats om Akhenatons solhymne med titlen De Hymnis in Solem sub Rege Amenophide IV. conceptis (Om solhymnerne som blev affattet under kong Amenophis IV). I bogen forfægter han den tese, at Akhenatons religiøse revolution var monoteistisk, og redegør desuden som den første for denne nye religions specifikke kendetegn. I modsætning til hvad man ofte læser, foretog han dog ikke i dette værk en sammenligning med Biblens monoteisme. Og selv om sammenkædningen ser ud til at have ligget i luften, blev den engelske ægyptolog og orientalist E. A. Wallis Budge den første til at foreslå, at Salme 104 kunne

1 Allerede i oldtiden blev denne distinktion observeret. Se Walzer 1949, 23-37; og Baltrusch 1998, 412 n.50. Derfor er bogtitler som f.eks. Herman Kees, Der Götterglaube im alten Ägypten i virkeligheden unsinnig, jf. Assmann 2003, 27. 
være en oversættelse af Akhenatons solhymne. ${ }^{2}$ Psykoanalysens fader, Sigmund Freud, beskæftigede sig gennem mange år med Moses-skikkelsen og spørgsmålet om monoteismens oprindelse. Kulminationen herpå blev bogen Der Mann Moses und die monotheistische Religion fra 1939, hvor Freud som den første foreslår, at monoteismen opstod som en 'modreligion' i Amarna-tidens Ægypten; reaktionen mod Akhenatons religion - i sig selv en 'modreligion' vendt mod den traditionelle ægyptiske religion - resulterede i et had så altomfattende, at erindringen om Akhenaton fortrængtes for siden at vende tilbage forklædt som Moses. Denne skulle i øvrigt have været en af Akhenatons nærmeste folk, og forbindelsen mellem de to religioner skulle forstås i lyset af dette faktum. Roden til antisemitisme skal derfor ikke søges i reaktioner mod jødedommen, men i monoteisme som sådan, i sidste instans Akhenatons religiøse revolution.

I de senere år er diskussionen om monoteismens oprindelse og karakter blevet genoptaget. Årsagerne hertil er flere, men blandt dem er den vold og voldsretorik, der tilsyneladende er en integreret komponent i de monoteistiske religioners virkningshistorie. Debattens hovedpersoner er Moses og Akhenaton. Om Moses gælder det, at der ikke findes levn og beretninger, som kunne tyde på, at han skulle være en historisk figur. ${ }^{3}$ Det gælder selvsagt ikke Akhenaton. Assmanns tese er nu, at allerede i antikken havde man kendskab til, hvad han kalder identifikationen mellem Moses og 'en forskudt erindring om Akhenaten'. ${ }^{4}$ Der er altså ikke tale om en faktisk historisk identitet, men om en identitet skabt i erindringshistorien. Hvor usandsynligt det end måtte lyde, så levede hadet mod Akhenaton og hans religiøse hærgen videre i det skjulte og blev i Sentiden overført på jøderne, da ægypterne kom i kontakt med dem. Hvordan hænger alt dette nu sammen?

Naturligvis kan man ikke helt løsrive den 'faktuelle' historie om begivenheder og personer fra historien om den rolle eller mangel på samme, som de selv samme kommer til at spille i en senere tradition (jf. Assmann 1997, 21, jf. 14 og 18). Det er således et centralt element i opbygningen af Assmanns tese, at den jødiske historiker Flavius Josefus, som i det 1. århundrede e.Kr. skildrede den jødiske 'stats' undergang og forudsætningerne herfor, tilsluttede sig den opfattelse, at de semitiske folk, der under navnet Hyksos herskede i Egypten i det 17. århundrede, måtte anses for at være de israelitter, der kom til Ægypten på Josefs tid.

Af største betydning er selvfølgelig også Assmanns billede af perioden. Amarnaperioden må have været indbegrebet af 'the Amarna period must have meant the utmost degree of sacrilege, destruction and horror for the Egyptians: a time of divine absence, darkness, and disease.' Men var perioden en tid med gru, må den fuldstændige udslet-

2 London 1902, 125 - ifølge Assmann 1997, 23, som igen er baseret på Erik Hornung 1992, 43-49, særligt $45 \mathrm{f}$.

3 I nyeste tid har den tyske ægyptolog Rolf Krauss argumenteret for, at Moses skulle være den bibelske forfatters sene (c. 500 f.Kr.) og romantiserede version af 19. dynasti faraoen Amenmesse, som Krauss opfatter som en usurpator, se 2001. For modargumenter se nu Kenneth A. Kitchen 2006, 148.

4 "a dislocated memory of Akhenaton", Assmann 1997, 24 
telse af alle erindringer om den have været lige så uhyggelig. ${ }^{5}$ Under Akhenatons regering blev ægypterne for første gang konfronteret med en fremmed, om end ikke helt ny religion. Kulten var stadig rettet mod solen, men nu på bekostning af alle andre guder. Templerne blev lukkede, billeder og kult ødelagt, og kulten af solen fandt nu sted under helt andre former. Oplevelsen må have været værre end den med Hyksos' herredømme i dele af Ægypten. Eftersom perioden i høj grad også blev arkæologisk udslettet, overlevede erindringen om den for det meste kun som et traume, der godt 40 år senere, 'when concepts of religious otherness came to be fixed on the Asiatics, who were Egypt's traditional enemies', blev projiceret over på Hyksos. ${ }^{6}$ Hvad Assmann mener med, at asiaterne bliver gjort til et særligt fjendebillede i Ramessidetiden, er ikke klart. Det er i den periode, skriver han, at fortællingen om Hyksoskongen Apophis og 17. dynasti faraoen Seqenre affattes(!); her stilles asiaternes religiøse praksis ganske rigtigt ikke i et godt lys. Men skønt man fra samme periode godt kunne pege på tekster, der tegner et noget andet billede, ${ }^{7}$ mener Assmann tydeligvis, at i Ramesside-perioden blev den 400 år ældre konflikt med Hyksos fordrejet til at blive en religiøs konflikt. Denne fordrejede version af de historiske forhold fortsatte gennem de følgende århundreder, som i stigende grad kom til at blive influeret af mødet med det religiøse anderledes i form af assyrere og persere. I denne proces blev Seth f.eks. til en rigtig fjendtlig gud, "både djævel og Asiat" (Assmann, 1997, 29).

Amarna-periodens afslutning faldt angiveligt sammen med en anden katastrofe, nemlig en pest, som via hittitterne nåede resten af Mellemøsten, inklusive Ægypten. Den var oldtidens værste og varede i ca. 20 år. Pesten blev kaldt den Asiatiske Syge og skulle være en anden af de faktorer, der bidrog til, at Amarna blev opfattet som en asiatisk fjende. Denne pest og den forfærdelige erfaring med den negative religiøse revolution skabte tilsammen et traume "which gave rise to the phantasm of the religious enemy."8 Henvisningen til en mulig forekomst af pest er dog højst usikker. Og hvis den sygdom, der hævdes at have ramt Ægypten, skulle være den Asiatiske syge, er der næppe tale om pest, men snarere om spedalskhed, ${ }^{9}$ hvad der, som vi skal se, ikke nødvendigvis svækker Assmanns argumentation.

I erindringshistorien udvikler dette traume sig nu på en meget mærkelig måde. Assmann bygger her videre på en tese, fremsat første gang af Eduard Meyer i 1904, og siden videreudviklet af Rolf Krauss og navnlig Donald Redford, nemlig den at erindringen om Amarna-perioden skulle være overleveret i sene beretninger om en gruppe spedalske, som både fordrives fra og siden tager magten i Ægypten sammen med Hyksos (se nærmere nedenfor).

5 Assmann 1997, 26f. Kilden til dette billede er først og fremmest Tutankhamons såkaldte Restaurationsstele, se nedenfor.

6 Assmann 1997, 28

7 F.eks. den såkaldte 400 års stele, som angiveligt er dateret til år 400, dag 4 i den 4 . sommermåned af guden Seths herredømme over Avaris.

8 Assmann 1997, 25 med henvisning til Hans Goedicke 1984, 91-105.

9 Se Bardinet 1988, 15-26; Quack 2005, 63-80; og senest Lange 2007, 47. 
Min [dvs. Assmanns] tese er, at traditionen om Hyksos først fik sin betydningsmæssige kolorit og karakter af at være en i al væsentlighed religiøs konflikt efter Amarnaperioden, eller for at være mere præcis, efter at Amarna-generationen var afgået ved døden og man var begyndt at sammenblande erindringen om Amarna med Hyksostraditionen. Først da begyndte Hyksos at fremtræde i rollen som tilhængere af en fremmed og antagonistisk religion. Amarna-perioden formede traditionen om Hyksos og skabte den semantiske ramme 'religiøs fjende', som derefter blev udfyldt af assyrerne, perserne, grækerne og til sidst af jøderne (Assmann 1997, 41, jf. 28 og 30).

Der er en interessant forskel i den måde, hvorpå problemet stilles op. Nogle af de ovennævnte ægyptologer finder erindringsspor af Amarna-perioden, begivenheder og lokaliteter, i Manethos historie. Redford foreslår således, at Manethos omtale af en slags koncentrationslejr for de spedalske i ørken skulle hentyde til flytningen fra Theben til Amarna! Andre har foreslået, at beretningen om de spedalske skulle hentyde til kongefamiliens legemlige deformitet, således som man også i sentiden kunne iagttage det på f.eks. grænsestelerne fra Amarna (Elanskaya og Belev hos Assmann 2003, 176, note 86). Herved bliver Manetho i øvrigt den første til at fremsætte hypotesen om sygdom som årsag til familiens mærkelige udseende. Assmann er ikke ude på at finde spor af konkrete begivenheder og steder i Amarna i den senere tradition, men derimod spor af det indtryk, som Amarna afsatte i traditionen:

\footnotetext{
My question, to resume, is not about "what really happened", but rather about what became of the recollections that must have existed in the form of individual remembrances and collective traditions, both in Canaan (of the Hyksos' sojourn in Egypt) and in Egypt (of the Armarna revolution. (Assmann $1997,41)$
}

\section{Akhenaton og de spedalske}

Hvor om alting er, hvori består nu den senere tradition? Her er tale om en række forskellige forfattere som f.eks. ægypterne Manetho og Chaeremon, den romerske forfatter Tacitus, og grækerne Strabo og Diodor (alle fra 1. årh. e.Kr.). Hos disse og andre antikke forfattere findes forskellige versioner af den beretning, som her skal gengives efter Manetho. Manetho var en ægyptisk præst, som under Ptolemæus II antages at have skrevet en Ægyptenshistorie. Værket er kun overleveret i uddrag hos andre forfattere, bl.a. hos Josefus, som i sin bog Mod Apion forsøgte at gendrive noget af al den bagvaskelse, som denne Apion og andre græsk-egyptiske historikere havde skrevet mod jøderne. I det ene uddrag beretter Manetho om Hyksos, som med stor grusomhed skulle have regeret i Ægypten i 511 år, hvorefter de blev tvunget bort. De drog så til Syrien, hvor de af frygt for assyrerne slog sig ned i det, der nu kaldes Judæa, og grundlagde Jerusalem (Fragment 42). I det andet uddrag, som Josefus citerer for at gendrive det som anti-jødisk propaganda, fortælles det (i referat): 
Kong Amenophis ønskede at se guderne, sådan som en af hans forfædre havde gjort det. Hans rådgiver Amenophis, søn af Hapu, forklarer kongen, at hans ønske kan opfyldes, under forudsætning af at han renser Ægypten for spedalske og andre smittede. Kongen samler derpå alle disse syge, i alt 80000 personer og sender dem sammen med nogle præster ud til stenbruddene i den østlige ørken. Amenophis, søn af Hapu, indser, at denne behandling er for hård. Kongen vil blive straffet derfor, ved at de spedalske skal herske i 13 år i Ægypten sammen med de udlændinge, som skal komme dem til hjælp. Det tør han dog ikke sige op i kongens åsyn, så han skriver det til ham, hvorefter han begår selvmord.

De spedalske får så lov at bosætte sig i Avaris, den gamle Hyksos hovedstad. Her vælger de en vis Osarsiph, en præst fra Heliopolis, til deres leder. Denne ønsker at lægge den størst mulige afstand til ægypterne og gør det ved først at gennemføre en anti-ægyptisk religiøs lovgivning og dernæst ved at søge hjælp hos Hyksos i Jerusalem, dvs. fra dem, som tidligere var blevet fordrevet fra Avaris. Da de kommer tilbage til Ægypten, forstår kongen, at Amenophis, søn af Hapus forudsigelse var korrekt, og han skjuler derfor gudebillederne og trækker sig så tilbage fra Ægypten med en stribe hellige dyr for at tilbringe de næste 13 år i Nubien.

Koalitionen af Hyksos og de spedalske udøver nu i Ægypten et sandt rædselsregimente, som får det tidligere Hyksos herredømme til at ligne en guldalder. Osarsiph tager navnet Moses og Ægyptens templer, helligdomme, og hellige dyr brændes af.

Efter de 13 år vender Amenophis og hans barnebarn Ramses hjem til Ægypten og fordriver de spedalske og Hyksos (Fragment 54). ${ }^{10}$

Selvom historien umiddelbart kunne lyde som noget tøjeri, indeholder den en række komponenter, som det er værd at se lidt nærmere på. Historien begynder med en problematisk situation: gudernes fravær. Dette er et velkendt træk i alle situationer, hvor der er indtrådt en ubalance i Ægypten. Den typiske situation er tomrummet ved et tronskifte, og blandt de mere interessante og relevante beskrivelser er en berømt passage i Tutankhamons såkaldte 'restaurationsstele', hvor kongen beskriver det sammenbrud og gudefravær, som den foregående Amarna-periode har fremkaldt. Kongen i Manethos beretning ønsker guderne tilbage, dvs. at se dem, men må først genoprette Maat. Hvem er kongen? Navnet Amenophis passer på flere konger; men den omstændighed, at hans rådgiver er Amenophis, søn af Hapu, peger på, at kong Amenophis kunne være Amenophis III, Akhenatons fader, hvis højre hånd, så at sige, netop var Amenophis, søn af Hapu. Vi kunne altså befinde os i perioden umiddelbart før Amarnaperioden.

For at genoprette tingenes rette tilstand må de spedalske, urene, uddrives. De bliver først samlet i ørkenen, siden i Avaris. Her vælger de en leder ved navn Osarsif. Denne står i spidsen for tre projekter. Det første er at skabe fundamentet for en anden religiøs ordning. Denne ordens elementer er karakteriseret ved at være de modsatte af

0 Manetho, s. $119 \mathrm{ff}=$ Menachem Stern 1974 vol. 1, 78-83. 
det, ægypterne gør eller anser for helligt. Hvad ægypterne forbyder, skal de spedalske gøre, og hvad ægypterne foreskriver, må de spedalske ikke gøre. De må således ikke dyrke guderne, ikke have hellige, og derfor urørlige dyr; de skal netop spise de dyr, man ikke må spise i Ægypten. ${ }^{11}$ Samtidigt lægger Osarsif grunden til det, der hos jøderne udviklede sig til en enklavekultur. Hermed menes en kultur, som oftest en minoritets kultur, hvis regler grundlæggende har til formål at drage og opretholde skarpe grænser til andre kulturer. Det forordnes således, at de spedalske skal holde sig fra omgang med andre - af hensyn til sig selv, ikke til de ikke-spedalske.

De spedalske regerer sammen med Hyksos i 13 år, dvs. lige så længe som opholdet i Amarna varede. Osarsif tager også navnet Moses. Hos alle andre end Manetho hedder de spedalskes leder kun Moses. Den ene af komponenterne i navnet Osar-sif er uden tvivl Osiris = Osar, således som allerede Manetho anfører. Den anden opfattes traditionelt som navnet på en mindre gud fra det nuværende Cairo-område, men ligesom Assmann er jeg ikke utilbøjelig til at have en stærk sympati for Thomas Manns forslag om tolke navnet som Osiris-Josef, således som han gør det i romanen om Josef og hans brødre. ${ }^{12}$ I Chaeremons version af historien er lederne af de spedalske netop Moses og Josef. I en tredje version er Moses søn af Josef.

\section{Akhenaton og jøderne}

Mens mange af de øvrige versioner har en klar anti-jødisk tendens, nævner Manetho, som altså her kun kendes fra Josefus, overhovedet ikke jøderne. Mange forskere antager, at bemærkningen om, at Osarsif tager navnet Moses, er en glosse, dvs. forklarende randbemærkning, hvis formål er at forbinde historien med Exodus-traditionen. Manethos version skulle derfor ikke være vendt mod jødedommen, som ganske vist har forbudt dyrkelsen af andre guder, men som ikke forfølger disse uden for eget territorium, dvs. uden for Kanaans land. Manethos version er derimod antimonoteistisk og repræsenterer angiveligt en reaktion på Amarna-periodens teoklasme, dvs. omstyrtning af guder. ${ }^{13}$ Josefus opfatter ganske vist Manethos beretning som vendt mod jøderne; men det skyldes, at han uden videre identificerer israelitterne i Ægypten med Hyksos, en antagelse, der, dengang som nu, ville passe fint ind i den jødiske-israelitiske og israelske selvforståelse.

Assmann og den tidligere forskning tillægger Tacitus' version en stor betydning, fordi den på en måde fungerer som en slags fællesnævner for de øvrige - og vel også fordi det er den version, der blev transmitteret ind i den europæiske kultur. I hans

11 Manetho, 127 og 131 = Menachem Stern 1974 vol. 1, 82f.

12 Hvor det bl.a. omtales som Josefs dødenavn eller underverdensnavn. Navnet hentyder til opholdet i brønden, der betegnes som indgangen til underverden, men peger også på en genopstandelse til et liv i Osiris land og til en social opstigning fra den tjenende klasses underverden, jf de mange refleksioner i i romanens bind 3, Josef i Egypten. Se også Assmann 2006c, 97-99.

13 Assmann 2003, 93f, jf. dog s.94 nederst; og Baltrusch 1998, 415 note 66. 
version $^{14}$ er der en epidemi i Ægypten. Kongen, Bocchoris - en konge fra det 24. dynasti, som man langt senere kunne have regnet som den sidste legitime konge inden nubiernes og assyrernes erobring af Ægypten i slutningen af det 8. århundrede f.Kr. - rådes af et orakel til at rense landet for jøderne. Deres leder, Moses, fører dem til Jerusalem, hvor han indfører en ny religion, der skal være det modsatte af andre religioner. Der skulle kun være én gud, og man måtte ikke gøre billeder af ham. Det, der er helligt hos os, anser de for at være profant, og det, der er hos dem er tilladt, er forbudt hos os. Tacitus er den første, der eksplicit beskriver den jødiske monoteisme som en modreligion, en religion som bevidst er vendt mod den ægyptiske og andre polyteistiske religioner. Jøderne ofrer tyre, fordi Apis er hellig i Æ Ægypten, og de ofrer en vædder for at 'forhåne Amon. '15 Også Strabo beskriver jødernes religion som en modreligion. I hans fremstilling lægges der stor vægt på, at Moses grundlagde en religion, hvor der kun var én gud. Denne gud måtte ikke afbildes og kunne heller ikke blive det, fordi han var i al ting, himlen, havet og jorden. ${ }^{16}$

Analysen af og sammenstillingen af de forskellige kilder er langt mere detaljeret, end jeg her kan gøre rede for. Assmann drager den konklusion, at 'historien om de spedalske kan (...) forklares som et iøjnefaldende eksempel på fordrejet og fejlplaceret erindring. Ifølge denne tradition overlevede mindet om Akhenatons monoteistiske revolution. Men fordi erindringen om Akhenatons navn og monumenter var bandlyst fra den kulturelle hukommelse, blev mindet fordrejet og genstand for mange slags transformationer og 'broderier". Atontilhængerne blev til spedalske og Akhenaton til Osarsif $(1997,39 ; 2003,88)$. Centralt i hans tolkning står redegørelsen for modsætningen mellem jødernes og ægypternes forhold til at afbilde gud. Et billede af en guddom ville hos jøderne ødelægge kontakten mellem Israel og dets transcendente gud, mens ødelæggelsen af et gudebillede for ægypterne netop ville afskære dem fra kontakten med deres gud. Som følge af Amarna-periodens ikonoklasme - billedstorm - udviklede ægypterne efter Assmanns opfattelse en fobi mod ødelæggelse af kultbilleder (Assmann 2003, 95ff). Tilstedeværelsen og fravær af billeder er begge af fundamental betydning for at sikre sig guddommens tilstedeværelse. Fra ikke-jødisk side forstås modreligionens krav om at ødelægge gudebilleder derfor som den største form for urenhed, som spedalskhed - på samme måde i øvrigt, som den tidlige kristendom sætter lighedstegn mellem hedenskab og spedalskhed, og, omvendt, 4 Mosebog forholder sig til spedalske som til dyrkere af afgudsbilleder. ${ }^{17}$

Det er langt fra nyt at tolke historien om de spedalske som et 'ægyptisk præludium til den europæiske antisemitisme' (Assmann 1997, 43). Den fjendtlige holdning antages at hidrøre fra den omfattende jødiske indvandring i Ægypten, som fandt sted efter Jerusalems fald til babylonerne. Som Assmann ser det, er der dog snarere tale om et

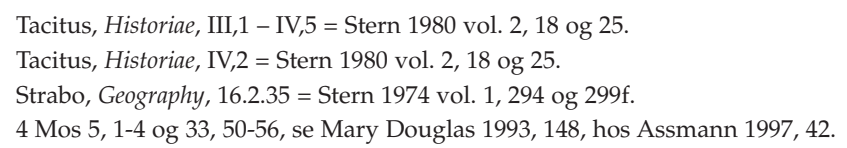


mnemohistorisk sæt af erindringsforskydninger (se nærmere nedenfor), der har den usædvanlige og utrolige konsekvens, at jøderne, som den sidste repræsentant for de fremmede asiater, og uden at have været i Ægypten førend efter ca. 500 f.Kr., ${ }^{18}$ blev ofre for det had, som historisk set var rettet mod Akhenaton og hans monoteistiske religion. ${ }^{19}$ Men selv hvis man ikke er parat til at acceptere denne forklaring, står det dog fast, at historiens første antisemitisme kan spores tilbage til Ægypten. Her findes de tidligste eksempler på, hvad der skulle blive stereotyper og klicheer i propagandaen mod jøder, og det er vigtigt at fastslå, at denne jødefjendtlighed er betydeligt ældre end kristendommen. Når vi derfor med Assmann tager næste skridt i diskussionen om monoteismens beskaffenhed og virkningshistorie, er det altså uden nogen brod mod nogen religion; ej heller handler det om det om at spille den ene ud mod den anden.

Det skal dog siges, at i almindelighed beror kritikken/fjendtligheden mod jøderne i oldtiden ikke på nogen egentlig indsigt i jødedommen, men derimod på dens religiøse praksis og dennes konsekvenser for samlivet med andre etniske grupper og nationer. Tacitus anfører således, at jøderne allerede fra begyndelsen må have været klar over, at virkningerne af deres modreligion måtte blive en kilde til mere eller mindre konstant krig, og at de derfor byggede Jerusalem som en svært indtagelig fæstning. ${ }^{20}$ Det var en udbredt opfattelse, at jøderne ikke kunne integreres i det romerske rige; de passede, som Cicero udtrykte det, ikke til Romerrigets glans!21

\section{Monoteisme og vold}

\section{Mnemohistorie og vold}

Med en oprindelig monoteisme, som frembragte en national katastrofe, med en jødedom, hvis enklavekarakter vakte omverdenens fjendtlighed, og på baggrund af såvel Holocaust som Islams kontroversielle rolle i nyeste tid, stiller Assmann nu det mere generelle spørgsmål, om der klæber et eller andet voldeligt ved den monoteistiske ide, om der er noget ved monoteismen, som fremprovokerer vold? For at tydeliggøre problemet introducerer han her et begreb voldens teologi, hvorved han forstår en 'teologisering af forskellen mellem ven og fjende. Vi har at gøre med voldens teologi, når denne

18 Assmann synes implicit at tilslutte sig det synspunkt, at den bibelske beretning om jødernes ophold i Ægypten savner enhver historisk realitet.

19 Assmanns begreb mnemohistorie betjener sig af et diskurs-begreb, som minder påfaldende om Claude Lévi-Strauss's myte-begreb, se nærmere nedenfor.

20 Tacitus, Historiae V,12.

21 'Each state, Laelius, has its own religious scruples, we have ours. Even while Jerusalem was standing and the Jews were at peace with us, the practice of their sacred rites was at variance with the glory of our empire, the dignity of our name, the customs of our ancestors. But now it is even more so, when that nation by its armed resistance has shown what it thinks of our rule', Cicero, Pro Flacco, $69=$ Stern 1974 vol. 1 , 196-8, jf. Baltrusch 1998, 414 note 56. 
efter omstændighederne politiske sondring tolkes teologisk, således at den politiske fjende bliver til Gudsfjende' 'i den forstand, at det er Gud, som definerer og sanktionerer forskellen.'22 Det er vigtigt for Assmann at slå fast, at det ikke er fakta som sådan, der er interessant. Eller rettere, han siger, (1) at den diskurs, man har ført i Europa om emnet - fra Oplysningstidens religionskritik, over antisemitismen og frem til vores dages kritik - (2) tillige med det faktum, at de senere års tilbagevenden af religion i foruroligende grad er ledsaget af vold, trusler, had, angst og skabelse af fjendebilleder, viser, at spørgsmålet er brændende aktuelt. Men, hævder han, netop problemets aktualitet viser, at 'det ikke [er] fortiden som sådan, men den form, som vores erindring antager, der er drivkraften og giver vores handlinger retning' (2003, 19). Det er altså ikke de historiske fakta, men mnemohistorien - erindringshistorien - om dem, det handler om. Mnemohistorie er beslægtet med det, han har benævnt 'kulturel semantik', hvorved han forstår de store fortællinger og fundamentale distinktioner, som et samfund bruger til at orientere sig i verden, og som udmøntes i myter, symboler, billeder og litterære tekster $(2003,21)$. I et interview i Le Monde i februar 2007 siger Assmann, at 'det, der interesserer mig, er måden, hvorpå noget transmitteres. Den lader sig ikke reducere hverken til den overlevering, hvorom vi er bevidste, eller som bruges i undervisning, men går ad talrige andre veje, via billeder, riter, symboler, fester, osv.'23 I sin bog Ägypten. Eine Sinngeschichte taler han om den form for historieskrivning, han kalder mytologisk. Hermed sigter han til den proces, hvorved signifikante begivenheder formes til en tradition. Dette er en grundlæggende funktion ved myten. Myten må ikke opfattes som noget, der er i modsætning til historieskrivningen. Tværtimod. 'Al historie, der som normativ tradition finder vej ind i en gruppes kollektive erindring, bliver til myte. Myter er erindringens grundformer, hvis bestandige gentagelse og aktualisering sikrer et samfunds eller en kulturs identitet. (...) Man kunne benævne denne tilgang mnemohistorisk, for det drejer sig her ikke blot om at erindre historien, men ligeså meget om erindringens historie' (1996, 22 = 2003, 10). I sine senere værker giver Assmann definitionen af mnemohistorie en lille drejning. Han sætter det nu i forbindelse med et diskursbegreb, som minder påfaldende om Claude Lévi-Strauss' mytebegreb (Lévi-Strauss 196, 213ff). Diskursen og myten rummer begge summen af samtlige versioner af henholdsvis temaet for diskursen og for myten. Forskellen ligger i fortællerens status, som 'videnskabsmand' eller som digter. For Assmann er mnemohistorie historien om vor kulturelle erindring, som igen kan forstås som historien om, hvordan en teksttradition bliver til (Assmann 1990, 45-48; 1997, 16f. 206a).

Hvis dette er rigtigt forstået, synes jeg, at Assmann har et problem; men det er et problem, han deler med ganske mange moderne historikere. Det, der er tale om, er nemlig intet mindre end spørgsmålet om, hvorvidt historie er andet end en tekst, noget

22 Assmann 2000, 161f. Assmanns artikel rummer en lang og meget vigtig nuancerende diskussion af denne definition,

23 Nicolas Weill 2007, 12 ("ce qui m'intéresse c'est le mécanisme d'une transmission qui ne se réduit pas à la tradition consciente ni à l'éducation, mais qui passe par beaucoup d'autres voies: via un fond d'images, de rites, de symboles, de fêtes, etc."). 
der kun eksisterer gennem historikerens arbejde. ${ }^{24}$ Det er der jo skrevet uendeligt meget om; men man kan næppe tænke sig et problem, der bedre egner sig til at illustrere denne debat, end det af Assmann stillede spørgsmål om, hvorvidt monoteisme som sådan rummer et element af vold, fordi troen på en eneste gud udelukker troen på andre guder og samtidig indfører en sondring mellem det sande og det falske, sand religion vs. falsk religion, sand gud vs. falske guder. Mit spørgsmål er: Er det ligegyldigt, om monoteismen faktisk har volden indbygget i sig, eller er det tilstrækkeligt at spørge om monoteismens virkningshistorie?25 Assmann har selv lidt svært ved at håndtere netop dette problem. I flere af hans værker forekommer argumenterende passager, hvor man finder en sammenblanding mellem de to argumentationsniveauer. Som et eksempel herpå kan man fremdrage en sætning, hvori han skriver, at fænomenet voldens sprog i de tre monoteistiske religioner og alle andre religioner, som grunder sig på et udelukkende sandhedsbegreb, unddrager sig al kritik og polemik (2003, 20). Sætningen kan læses således, at det er Assmann, som ikke vil kritisere religionerne. Den kan også forstås således, at religionerne gør krav på at blive forstået på en måde, der rækker ud over al kritik og polemik. En tredje læsning er, at det netop er, fordi så megen moderne vold kan forstås som afledt af disse skrifter, at man netop ikke bør holde de religiøse skrifter ansvarlige for misbruget. Jeg synes, den tyske sætning er uklar, ${ }^{26}$ men under alle omstændigheder er konsekvensen, at vi moderne mennesker, der er konfronteret med vold, som legitimerer sig med henvisning til de samme religioners skrifter, må stille os spørgsmålet om, hvordan vi skal bedømme forholdet (2003, 40). Assmann understreger: "Jeg spørger ikke 'Hvorfor blev monoteismen gennemført med vold?', men 'Hvorfor blev gennemførelsen fremstillet og erindret i voldens sprog?'" $(2003,22)$. Udgangspunktet er voldens sprog, ikke volden selv. Men de to ting er ikke lette at holde adskilte. Assmann siger således om den hebræiske bibels beretninger om anvendelsen af vold, at de ikke har nogen historisk realitet, men at det heller ikke vil være rigtigt at bortfortolke dem. "Det må dog betyde noget, at de bibelske tekster trækker det fulde voldsregister ud for at fortælle om, hvorledes monoteismen satte sig

24 Spørgsmålet berøres i 2003, 7f, hvor den centrale passage lyder: "Thus, the meaning that makes events memorable is not just retrospectively imposed, not merely the interpretative work of historians, who give history a structure and hence, according to Burckhardt, falsify it. No, such memorable meaning (...) is already inherent in the course of historical events as experienced by contemporary witnesses. To put it more technically, those experiences are themselves semantically organized. The world in which we live, act, and feel is a meaningful structure. Hence narration and the construction of fictions of coherence is not simply and solely the work of historians, but rather a necessary condition for any kind of historical awareness, any experience of history." (= 1996, 20).

25 Problemet kan i nogen grad minde om det klassiske venstreorienterede dilemma om, hvorvidt socialismen er en negativ størrelse. Her er svaret, at det skam ikke er tilfældet; det er kun de eksisterende historiske former for virkeliggjort socialisme, som har korrumperet den rene lære!

26 "Die Sprache der Gewalt in den heiligen Schriften der Juden, Christen, Muslime und vieler anderer auf einen exklusiven Wahrheitsbegriff gegründeter Religionen ist ein Phänomen, das zunächst einmal jenseits aller Kritik und Polemik verstanden werden will und das umso mehr, als, wie gesagt, die heutige Welt in bislang unbekanntem und von niemandem vorhergesehenem umfang von Gewalt heimgesucht wird, die sich auf Gott und die heiligen Schriften beruht." 
igennem. Men også her lønner det sig at anlægge et erindringshistorisk perspektiv, for så handler det ikke mere om spørgsmålet om, hvordan monoteismen rent faktisk satte sig igennem i Israel - om der var tale om en evolution eller revolution, om en gradvis transformation eller brug af voldelige midler - men derimod slet og ret om, hvordan de bibelske tekster selv erindrer sig denne proces. 'Der er efter min opfattelse ikke vundet noget teologisk eller historisk ved at ville benægte de bibelske teksters internalisering af en voldens semantik. Monoteisme er teoklasme. Sådan ser monoteismen sig selv, sådan fremstiller den sig selv $i$ de bibelske tekster, og sådan har den også virket i historien" (min fremhævning).27 Lidt længere fremme skriver han: "Den mosaiske skelnen lader sig ikke datere. Den står i teksterne, men siden Akhenatons tid har den utvivlsomt til stadighed manifesteret sig i den historiske virkelighed i forskellige grader af vold. Og så har den endelig ført til store forandringer $\mathrm{i}$ - $\mathrm{i}$ hvert fald - den vestlige og i den islamiske verden gennem en proces, som har strakt sig over flere århundreder." 28

Assmann har naturligvis ret $i$, at det ikke er monoteismen, der har bragt "vold, had og begrebet synd ind i en indtil da fredelig verden". Men man kan konstatere, at i monoteismens hellige tekster spiller voldens sprog og billeder en påfaldende stor rolle, større end hvad man finder i andre religioners hellige tekster. Og selv hvis f.eks. den såkaldte Københavnerskoles synspunkt på Israels historie ${ }^{29}$ skulle være rigtig - Assmann har ingen referencer hertil, men synes implicit at tilslutte sig dens grundantagelser - så stiller sagen sig bestemt ikke bedre: "Netop når man ikke anser begivenhederne for at være historiske, men for at være de sagn og legender, som et samfund bruger til at konstruere eller rekonstruere sig en fortid, der kan give mening og perspektiv til nutidige opgaver og problemer, når man altså ser begivenhederne som

27 Assmann 2003, 36f: "Es muss doch etwas zu bedeuten haben, dass der Monotheismus in den biblischen Texten die Geschichte seiner Durchsetzung in allen Registern der Gewaltsamkeit erzählte. Auch hier empfiehlt sich ein gedächtnisgeschichtlicher Wechsel der Perspektive. Es geht dann nicht mehr nur um die Frage, wie sich der Monotheismus in Israel de facto durchgesetzt hat, ob evolutionär oder revolutionär, in Form allmählicher Transformationen oder gewaltsamer Maßnahmen, sondern vor allem darum, wie dieser Prozess in den biblischen Texten selbst erinnert wird. Ich sehe keinerlei historischen oder theologischen Erkenntnisgewinn darin, diese den biblischen Texten eingeschriebene Semantik der Gewalt leugnen zu wollen. Monotheismus ist Theoklasmus. So sieht er sich selbst, so stellst er sich in den biblischen Texten dar, und so hat er sich historisch ausgewirkt" (min fremhævning).

28 Assmann 2003, 51: "Die Mosaische Unterscheidung lässt sich nicht datieren, sie steht in den Texten, aber sie wurde zweifellos seit Echnaton auch immer wieder einmal mit mehr oder weniger Gewalt in historische Wirklichkeit umgesetzt, und sie hat schließlich, in einem sich über viele Jahrhunderte hinziehenden Prozess, eine zumindest die westliche und die islamische Welt in ihrem Sinne verändernde Wende herbeigeführt."

29 En række forskere på Københavns Universitets Teologiske Fakultet har gennem mange år argumenteret for, at Det Gamle Testamente ikke har nogen større værdi som kilde til Israels historie. David og Salomon, for slet ikke at tale om Moses, er ikke historiske personer, osv. Københavnerskolens synspunkter er naturligt nok omstridte i den internationale debat. 
symbolske fortællinger, så bliver spørgsmålet om deres betydning så meget desto mere påtrængende."30

\section{Monoteisme og polyteisme}

Det er også en forudsætning for at forstå Assmanns position i denne sag, at han regner ægyptiske, babylonske, indiske og tekster fra den græsk-romerske antik til den form for monoteisme, hvorom man kan sige: 'Alle guder er en', en form for monoteisme, som han kalder den inklusive monoteisme. Den står i modsætning til den monoteisme, som siger: 'Der er ingen andre guder end gud', altså det han kalder 'eksklusiv monoteisme' (2006b, 24; jf. 2003, 52ff). Den første form er en naturlig udvikling af polyteisme, mens den anden er resultatet af en 'revolution', ${ }^{31}$ og verdenshistoriens første eksempel herpå er Amarna-religionen. Denne definition har givet anledning til betydelig kritik, og Assmann uddyber derfor synspunktet i Die Mosaische Unterscheidung.

Monoteisme og polyteisme er begreber fra det 17. og 18 århundredes teologiske debat. De er ekstremt uegnede til at beskrive oldtidens religioner. Spørgsmålet om guds enhed er ikke blot et tema for monoteismen, det er det centrale tema også i polyteismen, og det var faktisk forstået af enkelte allerede i det 17. århundrede. Som instrument til at beskrive og klassificere antikke religioner er begreber som enhed og flerhed ikke hensigtsmæssige. "Kriteriet er ikke Guds enhed, men derimod negationen af 'andre' guder."32 Og - afgørende - der er her tale om en teologisk diskurs, ikke (praktisk, levet), religion. Monoteisme er en teologisk ide, men det er polyteisme ikke (Assmann 2003, 53). Man kan derfor ikke finde ét tidspunkt, hvor revolutionen sker, men nok momenter, hvor der har været forsøg på at skabe en monoteisme. Det er således heller ingen relevant indvending, at næppe nogen monoteisme er i stand til at være det i streng forstand, dvs. uden formidlende instanser såsom engle, med et rigoristisk billedforbud, osv. Også her kan man tage Ægypten som et eksempel: Det er ikke afgørende, at der i Amarna ikke var tale om en renlivet monoteisme, fordi ikke blot solguden, men også kongen og dronningen var modtagere af en vis kult, fordi man tolererede Mnevis-tyren, solgudens hellige dyr, osv. Det afgørende er, at guderne og kulten i den traditionelle religion blev afskaffede og forfulgte - helt i overensstemmelse med den mosaiske skelnen. Her i Ægypten i det 14. århundrede f.Kr. blev der for første gang skelnet mellem sande og falske religiøse fænomener, og denne sondring blev omsat til en praksis med alle politiske, kulturelle, sociale og utvivlsomt også psykiske konsekvenser. "Akhenatons monoteistiske revolution var ikke blot den første, men også det mest radikale

30 Assmann 2006b, 22f: "Gerade wenn man diese Ereignisse nicht für historisch hält, sondern für Sagen und Legenden, in denen eine Gesellschaft sich eine Vergangenheit konstruiert oder rekonstruiert, die ihren gegenwärtigen Zielen und Problemen Sinn und Perspektive gibt, also für symbolische Erzählungen, stellt sich die Frage nach ihrer Bedeutung mit besonderer Dringlichkeit."

31 Se nærmere i Assmann 2003, 38ff. 55.

32 Se Assmann 2003, 49: "Nicht die Einheit Gottes ist das Kriterium, sondern die Negation 'anderer' Götter." 
og voldelige udbrud af en modreligion i menneskehedens historie."33 Den ægyptiske monoteisme i Amarna-perioden er et moment. Det kiksede; men Ægypten faldt ikke tilbage i den traditionelle polyteisme. Løsningen blev én gud, der manifesterede sig i de mange. Assmann har endelig også denne formulering: Monoteismens oprindelige idé er ikke, at der kun er én gud, "men at der ved siden af den ene sande Gud kun findes falske guder, som man under ingen omstændigheder må tilbede. (...) Det afgørende punkt er ikke enheden, men udelukkelsen."34

\section{Om vold og intolerance i Gamle Testamente}

I Assmanns arbejder om sammenhængen mellem vold og monoteisme indtager studiet af beretninger i Gamle Testamente en central plads. Det vil falde uden for rammerne af denne artikel at fremlægge en tekstnær gennemgang af hans analyse, så jeg skal nøjes med at fremhæve enkelte synspunkter. Assmann tager udgangspunkt i forskellige passager fra 2 og 5 Mosebog, især de passager, der omtaler de krav, som Gud stiller til israelitterne, hvis nogen af dem skulle forlade folden, så at sige. De drakoniske krav, der bl.a. indebærer at en mand kan blive nødt til at slå sine egne børn og andre nære slægtninge ihjel, stammer tilsyneladende, undertiden ordret, fra den assyriske kongerets krav til vasallerne. De assyriske teksters trusler er i princippet helt i tråd med den daværende verdens politiske forhold - herunder også ægyptisk praksis, som jo var, hvad jøderne ville befri sig for. Assmann følger her flere gammeltestamentlere, herunder en af sine kritikere, Othmar Keel, som har villet forklare sagen historisk. I kølvandet på Assyrerrigets sammenbrud i det 7. århundrede kom de jødiske teologer på den tanke at udfylde det således opståede magttomrum med at overføre, så at sige, storkongens krav til sine undersåtter til Jahve. Resultatet blev Loven, som gjorde jøderne uafhængige af udefrakommende despoter, men helt og holdent underkastet en anden despot. $^{35}$

Assmann tilslutter sig en sådan forklaring. Loven og den dermed forbundne, men frivilligt indgåede pagt var også efter hans opfattelse instrumentet til befrielse fra det ægyptiske slaveri $(2003,67 ; 2000,169)$. Den deraf afledte disciplinering var (og har været) jødernes styrke; men hvor Keel mener, at Pentateukens billede af en skinsyg

33 Assmann 2003, 50: "Entscheidend ist vielmehr, dass, ganz im Sinne der Mosaischen Unterscheidung, die Götter und Kulte der traditionellen Religion abgeschafft und verfolgt wurden. Hier, im Ägypten des 14 . Jahrhunderts v. Chr., wurde zum ersten Mal zwischen wahr und falsch in Dingen der Religion unterschieden und diese Unterscheidung mit allen politischen, kulturellen, sozialen und zweifellos auch psychischen Konsequenzen in die Praxis umgesetzt"'; samme 1997, 25: "The Monotheistic revolution of Akhenaton was not only the first but also the most radical and violent eruption of a counter-religion in the history of mankind."

34 Assmann, Die Mosaische Unterscheidung, 52: "sondern, dass es neben dem Einen Wahren Gott nur falsche Götter gibt, deren anbetung aufs schärfste verworfen wird. (...) Der entscheidende Punkt ist nicht die Einheit, sondern die Exklusion".

35 Othmar Keel 2004, parafraseret efter citatet hos Assmann 2006b, 30. Jf. også Assmann 2000, 169 note 39, og 2006c, 9 note 2 for yderligere henvisninger til værker af Eckart Otto og Hans Ulrich Steymans. 
Gud tilhører passager fra en endnu ikke moden monoteisme, siger Assmann, at det tværtimod er karakteristisk for den eksklusive monoteisme, at dens gud er skinsyg. Den skinsyge gud har sine rødder i dels i den udfrielse og udvælgelse, som Exodus implicerer, dels i pagten. Assmann følger her også den antikke teolog Laktants (c. 250325), der i en afhandling Om Guds Vrede sondrer mellem Guds natur og Guds herredømme. Skinsygen er forbundet med Guds udøvelse af magt (2006d, 10f). De passager i Mosebøgerne, som indeholder disse barske beskrivelser, hører til Toraens kernestykker, og dertil kommer, at Guds krav og syn på menneskene modsvares af disses opfattelse af Gud. Menneskene er i deres forhold nidkære, således som en række eksempler viser, og bag vores oversættelser 'skinsyg' (Eifersucht) og 'nidkær' (Eifer) ligger samme rod qanna' (ordet gengives på græsk med zelos, jf. zelotisme, svarende til Arabisk djihad; 2003, 45). Her er ikke tale om et marginalt fænomen, men tværtimod om noget helt centralt. Skinsygen og nidkærheden retter sig først og fremmest mod de nærmeste, og en af de almindeligste metaforer for forholdet er netop brylluppet, der kræver troskab af parterne. Ordet troskab (Treue), hebræisk emunah, er det ord, vi gengiver med 'tro' (Glaube): "Voldens sprog hænger sammen med nidkærhed og troskab, med angsten for forførelse og de frygtelige trusler om straf, som er knyttet til frafald, utroskab og ægteskabsbrud."36

De voldsomme krav til de nærmeste afspejler sig også i de passager i Mosebøgerne - et godt eksempel er 5 Mos 20,15-18 - hvor der er tale om krigsret, dvs. hvordan man skal forholde sig, når man angriber andre byer. Uden for Kanaans land gør man, som man gør overalt i Orienten. Hvis byen overgiver sig, skal dens indbyggere være slaver el. lign. Hvis den ikke overgiver sig, dræber man dens mænd, når den er erobret, og tager børn og kvinder med som bytte. MEN når det drejer sig om egne byer og byer i Kanaan, skal ALT og ALLE brændes, og der må aldrig mere være en by på stedet. ${ }^{37}$

Af altafgørende betydning for Assmanns argumentation er hans synspunkt, at Det Gamle Testamente, og strengt taget også Det Nye Testamente og Koranen, er performative skrifter, kanoner, som skal efterleves. En ekstrem form for efterleven og lydighed er martyriet, som for første gang findes i Makkabæerbøgerne. Martyrium betyder at dø for loven. Både at dræbe og at dø for loven er de yderste ekstremer for påbuddet om ikke at have andre guder(2006b 49; 2003, 35). Men også konvertering spiller en afgørende rolle heri. Man kan ikke konvertere til en hedensk religion, hvorimod monoteismen næsten forudsætter en konvertering, et brud, fordi den kræver en sondring mellem sandt og falsk. Assmann er tilbøjelig til at se Det Gamle Testamente som en

36 Assmann 2006b, 36: "Die Sprache der Gewalt hängt mit Eifersucht und Treue zusammen, mit der Angst vor Verführung und den furchtbaren Strafandrohungen, die auf Abfall, Untreue und Ehebruch stehen." I artiklen 2006d, 8, eksemplificerer Assmann argumentationen med henvisning til den danske karikaturkrise. Se også 2003, 67f.

37 Assmann 2006b, 38-42. Han tilføjer, at denne 'krigsret' er en ren fiktion og aldrig har været i brug, men at den er en del af den kulturelle semantik og derfor har kunnet omsættes til historisk virkelighed. Der er intet reelt belæg for dette synspunkt, som genfindes i alle de mange tekster, hvor Assmann mere udførligt gennemgår Mosebøgerne, se f.eks. 2006d, 7. 
kodificeret erindring om en kulturel kollektiv metamorfose af et samfund, der gentagne gange har været udsat for ekstrem undertrykkelse (2006b, 50f).

\section{Den ægyptiske og jødiske monoteisme}

Der findes i Assmanns mange arbejder om monoteismen flere ansatser, som peger ud over kristendommen og islam frem til vore dage. Men i hovedsagen bliver han stående ved teorien, erindringshistorien - og oldtidshistorien. Det er her, det begynder, og det er her, vi har mulighed for at følge de første sekundære, monoteistiske religioners tilblivelse, og jeg skal da afslutningsvis sige et par ord om forholdet mellem Amarnareligionen og den mosaiske skelnen.

Akhenatons monoteistiske revolution adskiller sig fra Biblens ved at være reel. Revolutionen var en samtidig historisk begivenhed. Her er ikke tale om en teologi, som projicerer sin nutid tilbage til en fortid. Akhenaton har ikke krævet: 'I skal ikke have andre guder ved siden af Aton'! Han har afskaffet de øvrige guder uden nogen videre diskussion! Der er tale om en konkret, praktisk eksklusion, ikke en sproglig og teoretisk. Men eftersom denne handling ikke udviklede sig til en sprogligt artikuleret, kodificeret og kanoniseret erindringsfigur - blev til en bibel, så at sige - finder Assmann det mere hensigtsmæssigt at anvende termen den mosaiske skelnen, snarere end Amarna-religionens skelnen.

Der er stor forskel på Akhenatons og Biblens monoteisme, til trods for at de begge opfylder kriteriet for at være en eksklusiv monoteisme. Akhenatons monoteisme introducerede et nyt verdensbillede (kosmologi). Den var baseret på den erkendelse, at Solen ikke alene producerede alt liv, lys og varme, men også tid. Fordi den også genererede tiden, drog Akhenaton den slutning, at de øvrige guder var overflødige, løgn og bedrag, og deres kult kunne dermed nedlægges. Hos Moses drejer det sig ikke om en ny kosmologi, men 'en ny politisk orden, om lovgivning, forfatning, pagt og bånd.' I modsætning til Akhenaton, der ifølge Assmann ikke tillader andre guder, siger Biblen ikke, at der ikke er andre guder, men at du, Israel, ikke må have andre. 'Ellers ville kravet om troskab også have været meningsløst. Det benægtes ikke, at der er andre guder, men de bliver forbudte." I Ægypten står Amarna-religionen i modsætning til et falsk verdensbillede, hvor der i Israel foreligger troskabsbrud/aftalebrud (2003, 5759).

Den revolutionære, eksklusive monoteisme forstås kun, når man betragter den ud fra den polyteisme, den retter sig imod. Den fremgår jo netop ikke evolutionært af polyteisme, men har afgrænset sig fra hedenskabet. Både Akhenatons og Moses religion forholder sig her til den traditionelle ægyptiske religion, hvor gud, som det er tilfældet i polyteistiske religioner, ikke er adskilt fra verden. Heraf følger, at verden må have en flerhed. Polyteisme er derfor kosmoteisme. I monoteismen frigøres det guddommelige fra denne symbiose og bliver en selvstændig størrelse; men frigørelsen gælder også mennesket, der hermed indtræder som partner med den gud, der nu er adskilt fra 
verden. Det er netop menneskets forandrede status, der bevirker, at man f.eks. efter Amarna ikke blot kunne gå tilbage til situationen før Amarna. Der er sket noget med mennesket, som ikke sådan kan gøres om. Vi moderne kan heller ikke vende tilbage til et 'Ægypten'. Vi har haft vores exodus fra Ægypten.

Om forskellen mellem den ægyptiske og jødiske monoteisme siger Assmann, at de i visse henseender er hinandens antipoder. I Ægypten i Amarna-perioden finder vi et sammenfald mellem brugen af den 'mosaiske skelnen' og en ny, og ekstrem forening af herredømme og frelse. Den ene gud i Amarna er blandt andet karakteriseret ved ikke at være tilgængelig, dvs. forståelig, for andre end kongen. Denne træder derfor til og præsenterer sig for mennesket som gud og som mål for den individuelle fromhed. Den, der slutter sig til ham, finder frelsen. Den, der ikke gør det, møder guds vrede, som der står i en tekst fra Tutus grav i Amarna (Grav nr. 8. Se Sandman 1938, 86, 15-16; oversættelse i Murnane 1995, 198). Akhenaton har monopoliseret forbindelsen mellem gud, menneske og samfund på en mere radikal måde end tidligere. 'I ham vinder den faraoniske hybris og statsforgudelse, mod hvilket Exodus-myten vender sig, sin mest ekstreme form.' Aton er ikke en transcendent gud, han er solen, men alligevel finder vi sondringen mellem sandt og falsk. Gud - Aton - får sit navn i kartoucher og indgår i en slags samregering med kongen. Kongen repræsenterer derfor ikke, som tidligere, guden, men de hersker begge, den ene som kosmisk, den anden som politisk-moralsk magt. Derfor forbindes herredømme og frelse. Noget lignende findes også i omkredsen af den tidlige jødiske, kristne og især islamiske monoteisme i form af et teokrati. Så snart monoteismen ophørte med at være en 'modstandsbevægelse', slog den politiske teologi let om fra kritik af staten til legitimering af samme (Assmann 2003, 69f).

Samtidigt med at den jødiske monoteisme påbegynder sit skel mellem sandt og falsk, skiller den herredømme og frelse. Den transcendente gud vil ikke lade sig repræsentere af en jordisk herre. I sin egenskab af herre over historien har han også magten over frelsen. Derved forsvinder, som tidligere nævnt, kongedømmet. 'I jødedommen antager det form af en eskatologisk Messianisme, og i kristendommen opfyldes det ved Jesus Kristus og hans rige, som ikke er af denne verden' (Assmann 2003, 70).

Det er altså ikke guddommens beskaffenhed - konstitution - der er afgørende for, om vi taler om monoteisme. Kristendommens gudsbegreb - tre i én - er jo heller ikke ligefremt indlysende klart. Assmann skelner strengt taget også kun mellem en inklusiv og en eksklusiv monoteisme, og det vigtigste skel er da det mellem sandt og falsk, som vi har set.

Biblen befrier jøderne for den ægyptiske opfattelse, at mennesket ikke kan leve uden en (stærk) stat. Denne bliver nu erstattet med en stærk gud. Gud sættes i stedet for farao og de assyriske og babylonske storkonger. Den bibelske religion er dermed arvtager til disse stater, ikke til deres religioner. Man kan også sige, at en stat i form af et teokrati afløser de gamle sakrale kongedømmer. ${ }^{38}$

38 Assmann 2006d, 14-19, hvor det senere historiske forløb væk fra denne 'model' også kort skitseres. 


\section{Kritikken}

Assmanns bøger og artikler om monoteismens pris har vakt stor opsigt rundt omkring i verden, og mangen en læser har efter endt læsning måttet spørge sig selv, om det virkeligt kan passe, hvad forfatteren skriver. Er der en sammenhæng? Det har, som nævnt i indledningen, heller ikke skortet på kritik i form af bøger, artikler, og konferencer. En søgning på Assmann og Moses på Google i marts 2007 gav således 58.500 opslag! Kritikken er langt fra forstummet - og det er Assmanns forskning i emnet så sandelig heller ikke. Der er ingen tvivl om, at han har taget et yderst centralt og kontroversielt emne op til behandling, og det har været formålet med denne artikel at give et dansk publikum mulighed for at stifte bekendtskab hermed.

I både forarbejderne til Moses the Egyptian og i selve bogen malede Assmann med en bred pensel. Dele af bogen blev skrevet som i en rus, skriver han selv. I afhandlingen fremlagde han et meget omfattende materiale, og argumentationen udspændte en bue, der kronologisk strækker sig over flere årtusinder. En sådan intellektuel kraftpræstation aktualiserer altid problemet om helhedens forhold til sine bestanddele, herunder ikke mindst brugen af de mange forskelligartede kilder. Som udgangspunkt er synteseskabende værker sårbare over for kritik af detaljer, hvor specialister fra forskellige fag ikke er sene til at køre frem med skytset. Det har også været tilfældet med Assmanns værker om monoteismens pris, og der skal bestemt ikke lyde en kritik af denne fremgangsmåde. En teses holdbarhed beror helt indiskutabelt på dens empiriske fundering, men så sandelig også på dens indre logiske sammenhæng og forholdet mellem disse faktorer og tesens abstraktionsgrad. Kritikken har hidtil i al overvejende grad gået på Assmanns håndtering af sine data, og her er der leveret vægtige bidrag. Fra ægyptologisk side er det således blevet påpeget, at Assmann tegner et urigtigt billede af Akhenatons religiøse reform; forfølgelsen af de traditionelle guder var kun rettet mod Amon og nogle få andre guder, og kun på et uhyre begrænset antal lokaliteter. ${ }^{39}$ Rolf Krauss har også sat spørgsmålstegn ved Assmanns brug af Manetho, som Krauss ikke anser for at være en kilde fra Ptolemæertiden, men derimod fra romersk tid (2006, 227-34). Anmeldere og kritikere har anholdt gyldigheden af Assmanns anvendelse af en række forskellig begreber så som modreligion og har også stillet spørgsmålet, hvad kristendommen og jødedommen er for størrelser. Det springende punkt i Assmanns argumentation er dog nok hans brug af begrebet mnemohistorie, her især den 'håndværksmæssige' behandling af kildematerialet, det være sig den sekundære litteratur. De antikke forfattere diskuteres således uden noget forsøg på at afgøre deres mulige indbyrdes afhængighedsforhold. Det er heller ingen let sag, men det nytter heller ikke noget blot at ophobe varianter af 'samme' beretning uden at gøre sig sådanne overve-

39 Se Krauss 2000, 93-101, hvori også findes henvisning til tidligere forskning. Den grundlæggende tanke Assmanns opfattelse støttes imidlertid af en nærmere analyse af den måde, hvorpå navnet Aton skrives i hieroglyfskriften, se Orly Goldwasser 2006, $275 f$. 
jelser. De kulturelle stereotyper i argumentationen er heller ikke lige vel begrundede - og sådan er så meget blevet fremhævet i utallige anmeldelser.

Kritikken af delene har imidlertid ikke endnu rokket afgørende ved den utroligt provokerende og interessante tese, som Assmann har fremsat og elaboreret i sine mange værker om monoteisme. I den internationale debat har man, naturligt nok, ikke hæftet sig specielt ved Assmanns redegørelse for de ægyptiske data - det skal man være ægyptolog for at gennemskue - og der er for mig se heller ingen tvivl om, at Assmanns tese om den mosaiske skelnen kan bestå, selv hvis hans opfattelse af Akhenatons rolle heri skulle vise sig ikke at være holdbar (jf. Assmann 2003, 88f).

\section{LITTERATUR}

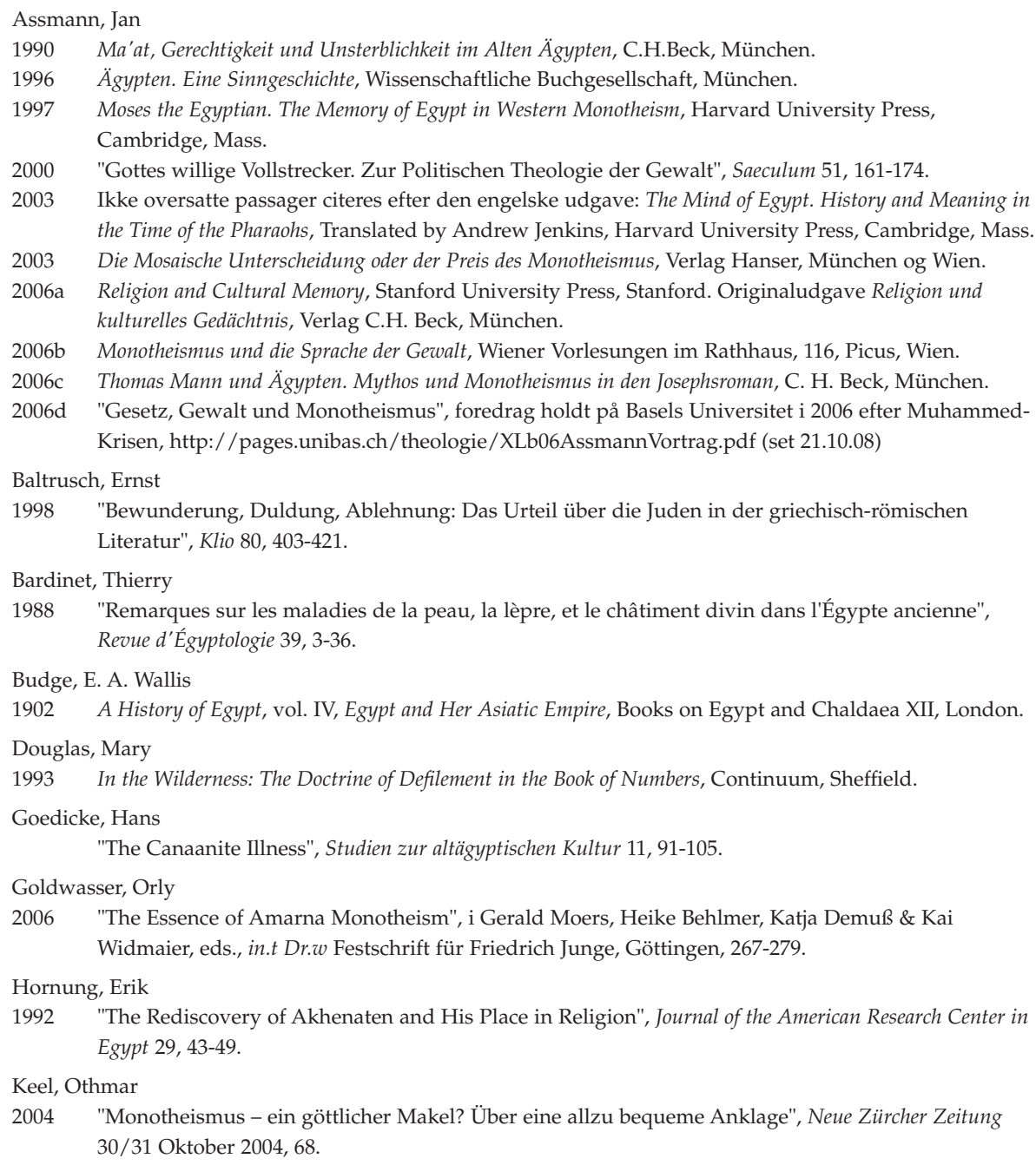

1992 "The Rediscovery of Akhenaten and His Place in Religion", Journal of the American Research Center in Egypt 29, 43-49.

2004 "Monotheismus - ein göttlicher Makel? Über eine allzu bequeme Anklage", Neue Zürcher Zeitung 30/31 Oktober 2004, 68 . 
Kitchen, Kenneth A.

2006 Anmeldelse af Pierre Grandet, Catalogue des ostraca hiératiques non littéraires de Deir el-Médineh, T. IX. Nos 831-1000, (= Documents de Fouilles, 41), Cairo 2003, i Chronique d'Égypte 81, 147-149.

Krauss, Rolf

2000 "Akhenaten: Monotheist? Polytheist?", The Bulletin of the Australian Centre for Egyptology 11, 93-101.

2001 Das Moses Rätsel. Auf den Spuren einer biblischen Erfindung, Ullstein, München.

2006 "Manethos ägyptische Geschichte - eine ptolemäische oder römische Kompilation?", i Ernst Czerny, Irmgard Hein, Hermann Hunger, Dagmar Melman \& Angela Schwab, eds., Timelines. Studies in Honour of Manfred Bietak; bind. 3, Orientalia Lovaniensia Analecta 149,3, Peeters, Leuven, 227-234.

Lange, Eva

2007 "Kretischer Zauber gegen asiatische Seuchen. Die kretischen Zaubersprüche in den altägyptischen medizinischen Texten', in Rainer Hannig, Petra Vomberg \& Orell Witthuhn, eds., Marburger Treffen zur altägyptischen Medizin. Vorträge und Ergebnisse 2002-2007, (= Göttinger Miszellen, Beihefte 2), Göttingen, 47-55.

Lévi-Strauss, Claude

1967 "The Structural Study of Myth", in: id., Structural Anthropology, Doubleday Garden City, New York, 202-228 (oprindeligt publiceret i 1955).

Manetho

1940 Manetho, The Loeb Classical Library, 350, William Heineman og Harvard University Press, London og Cambridge, Mass.

Murnane, William J.

1995 Texts from the Amarna Period in Egypt, Writings from the Ancient World Society of Biblical Literature 5, SBL, Atlanta.

Quack, Joachim Friedrich

2005 "Tabuisierte und ausgegrenzte Kranke nach dem 'Buch vom Tempel'", i Hans-Werner Fischer-Elfert, ed., Papyrus Ebers und die antike Heilkunde. Akten der Tagung vom 15. - 16.3.2002 in der Albertina/UB der Universität Leipzig, Harrassowitz, Wiesbaden, 63-80.

Sandman, Maj

1938 Texts from the Time of Akhenaten, Bibliotheca Aegyptiaca 8, Bruxelles.

Stern, Menachem

Greek and Latin Authors on Jews and Judaism. Edited with Introductions, Translations and Commentary, bind 1, From Herodotus to Plutarch; bind 2, From Tacitus to Simplicius, bind 3, Appendixes and Indexes, The Israel Academy of Sciences and Humanities, Jerusalem 1974, 1980 and 1984.

Strabo

1930 The Geography of Strabo VII, The Loeb Classical Library 241, William Heineman og Harvard University Press, London og Cambridge, Mass.

Tacitus

1959 Historien, München

Walzer, R.

1949 Galen on Jews and Christians, Oxford University Press, Oxford.

Weill, Nicolas

2007 "Jan Assmann, 'Dissident' de l'égyptologie", Le Monde, 23. februar 2007, 12.

Paul John Frandsen, lektor emeritus Carsten Niebuhr Instituttet, Københavns Universitet 